\title{
Barriers and Role of Higher Educational Institutes in Students' Mental Well-being: A Critical Analysis
}

\author{
Shruti Agrawal ${ }^{1, *}{ }^{*}$ Nidhi Sharma ${ }^{1}$ \\ ${ }^{l}$ Department of Humanities and Social Sciences, Malaviya National Institute of Technology, J.L.N. Marg, \\ Jaipur, Rajasthan-302017 (India) \\ "Corresponding author.Email:2019rhs9506@mnit.ac.in
}

\begin{abstract}
The concept of mental well-being includes all other perspectives like social, emotional, and psychological mental well-being. Rational mental well-being means the process that can think, feel, and react in various circumstances as per one's decision. Many mental disorders manifest themselves in the age of between 18 and 24 , which is proportional to the average age of student enrolment in higher education. The study aims to explore the critical barriers that affect the mental well-being of students in higher education and the role of sustainable education in promoting the well-being of students. We have identified various barriers from an extensive literature review of higher education students in a developing country. In the analyses, we have found that academic stress is the most significant barrier for the students, especially after the COVID-19 pandemic in the Indian context.
\end{abstract}

Keywords:Mental Well-Being; Students; Higher education; Sustainable Education; Sustainability; Sustainable Development.

\section{INTRODUCTION}

Mental health problems have become a significant subject among students. In terms of Higher Education, mental well-being has become important that has to be emphasized [1]. According to the holistic approach of education, learners' mind, body, and spirit encompass psychological, social, and mental wellness. The increase in awareness of mental health directly affects student development and their achievements. Substantial evidence that mental health problems appear among university students [1,4,7]. Emotional issues such as depression, stress, high anxiety have been known as common symptoms experienced and potentially threatening students' lives and cause mental health problems $[3,4,5,7]$. Mental health issues have an appalling impact on students. Academically, it causes students to have low academic performance and achievement, even study failure [4]. Mental well-being is a universal phenomenon in almost every sector like entrepreneurship, industry, job, administrative, and academic. Mental well-being is also supported by the report of the World Health Organization. India is the $2^{\text {nd }}$ most populated country in the world after China. India's higher education system is one of the largest globally, after the United States of America and China [6].

Still, in India, only $2.5 \%$ of colleges/universities run doctoral degree programs, and $34.9 \%$ of colleges run post-graduation programs (AISHE 2018-19). According to the Quacquarelli Symonds (QS) World University ranking, an annual listing of the world's top universities, Indian universities have stood in the top 200, released in June 2020. No Indian university has scored top 100 positions of QS World ranking. Education plays a significant role in imparting knowledge and training to individuals in the education sector and promoting better life opportunities [8,9]. The term "well-being" exhibits feeling satisfied with life, good health, happiness, and prosperity (UNESCO). In any society, when the population is educated, they will be able to utilize their knowledge, skills, information, and values to enhance society's development, required changes, and well-being. Mental well-being can be defined as a state of well-being where the learning potential of people can be improved, and people can cope with their stress and have a friendly environment around their community and family. However, there is no universal "definition" of well-being because the perspective and connotation of well-being differ 
from individual to individual, community-wise, and culture-wise. It could mean a notion of happiness for one but others, it could be a state of diseases free, and for some, it could be economic prosperity and achievement of goals.

The concept of mental well-being includes emotional, cognitive, and behavioral at the individual level. External stimulants and other factors can also determine the interpretation of mental well-being. According to the World Health Organization (WHO), "mental well-being is a state of well-being in whisch an individual realizes his or her capabilities, can cope up with normal stress of life, can work fruitfully and productively, and can make a contribution to the community." Generally, the issues related to mental health start from the age of 14 years old when students are young and threequarters by 25 years old when students are in a higher education level [10]. The main features to promote mental well-being in higher education are to provide social and emotional skills programs to build resilience by developing positive social connections, pro-social values, and positive self-regard, to focus on health, safety, wellbeing, and physical activity participation in the college events [11]. By the year 2030, the new strategy of United Nation Educational, Scientific and Cultural Organization (UNESCO) is to promote the opportunities for better health and wellbeing of all young people and children and support the education sector of UNESCO under the aid of public health threats. Its objectives are to promote the Sustainable Development Goals (SDG), particularly SDG 3 (health and well-being), SDG 4 (Education), and SDG 5 (Gender Equality) [13].

\section{FRAMEWORK FOR THE STUDY}

In the study we have discussed about the various barriers to mental well-being in students. How these barriers affect the mental well-being of students? How to overcome from these barriers. Role of mental being in the Indian educational institutes is also discussed. We have developed the relationship between mental well-being and sustainability and explains how sustainable education can enhance the well-being in higher education. In the end of study, we have discussed the sustainable outcomes and benefits in terms of economic, social and environmental perspective.

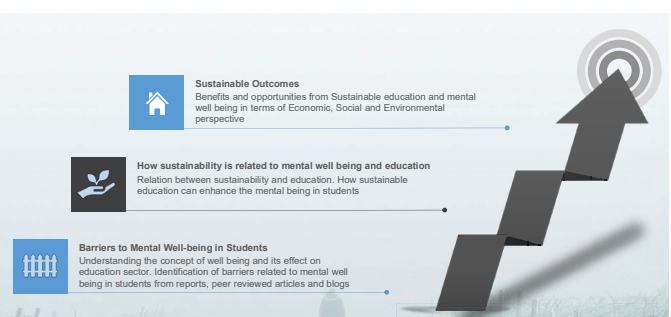

Fig 1: Framework for the study

\section{MENTAL WELL-BEING IN THE CONTEXT OF HIGHER EDUCATION: LITERATURE REVIEW}

The very Common stressors for students in college include enormous reasonable academic demands, remain on their own in a new environment, the shift in family relations, changes in social and personal life, interaction with new people, and their ideas [17]. The problems that challenge higher education in India are less enrolment rate, unequal access, penurious quality of infrastructure, poor teaching quality, a shortage of funding, inadequate facilities, unemployed graduates, an ordinary level of academic research, and that too declining [18]. There is a long road ahead imbalance in the demand-supply in the education sector in developing countries.

It is estimated that around $20 \%$ of the world's youngsters have a mental health problem, with anxiety disorders and depression mainly contributing to the global burden of disease for people aged 12 to18 $[19,20]$. To consider several articles published on the psychological distress of college students, it can thoroughly be concluded that 20 to 25 percent of the worldwide student population is going through psychological distress $[21,22]$. It is also stated that anxiety prevalent among students of higher education is harmful to their overall wellbeing in general, and ultimately it leads them to maladjustment in academics. A study examined revealed that Indian students were more prone to anxiety disorders than Iranian postgraduate students [15]. College students comparatively have more complex problems at the current time than they had over a decade ago [16].

In order to prevent students from suicidal tendencies, hopelessness and anxiety, various universities believes that it cannot be accomplished without organizing mental and behavioral health concerns for the students $[14,18,28]$. In some of the countries, universities and colleges have adopted various measure to cope with this problem and introduced counselling services for the students, enhanced the scope of sports and co-curricular 
activities, adopting Art Reduction Theory (ART), time spent in the nature has also been emphasized $[20,23,27]$.



Figure 2: Publication series from year 2006-2021

The above graph shows the trend of year wise publication of studies related to importance of wellbeing in the higher institutions. Majorly the focus has been diverted in this segment from year 2018.

According to the (WHO), 35\% of college students struggle with mental illness. At the same time, mental illness represents a world's challenge at the heart of the (WHO)'s Mental Health Action Plan 2013-2020. Researchers in positive psychology have long called for a shift in focus from the sole investigation and repair of human shortcomings, deficits, and pathologies to the construction and implementation of individual strengths, resources, and ultimately positive mental health $[21,23]$. The author has argued that most research has equated mental health with the absence of psychopathology [24]. Neglecting WHO's a positive definition of mental health as "a state of well-being in which the individual realizes their ability. It can cope with the normal stresses of life, work productively, and contribute to their community [25]. The term "mental well-being," "mental wellness," "mental health" are used interchangeably.

The world pandemic of coronavirus (COVID-19) has differently hit the education sector in the economy. The shift of education from traditional learning to online or blended learning was challenging to adapt to and changed learners' learning styles [26]. It has had both a positive as well as negative impact on the well-being of Indian students of higher education [27]

\section{OBJECTIVES OF THE STUDY}

1.) The study's main objective is to determine the role of Sustainable Education in promoting the well-being of students.

Table 1: Barriers with their description
2.) To study the various barriers that affect the mental well-being of Indian students in the higher education sector

\section{METHODOLOGY}

The methodology of the present study is reflected in Table 1. We have finalized 21 articles that were refined among the available literature that highlights the perceived barriers or challenges in the students or adolescents of higher education through searches of Scopus, Web of Science, and Google Scholar. A comprehensive analysis was undertaken of the quantitative and qualitative literature studies.

\section{BARRIERS TO WELL-BEING IN HIGHER EDUCATION}

The article presents a review of the literature presents the various detrimental barriers that affect the mental well-being of students. The term barriers are defined as anything cause triggers the mental health of the students in the higher education sector $[18,20]$. All the barriers 20 are clustered into various categories, and then subcategories were defined under them.

In the study, we have followed Scopus, Web of Science, and Google Scholar databases to collect the article by using the search strings. Such keywords were extracted for each of such concepts by examining the related terminology used in the review papers. Studies published on literature review analysis have discussed the significance of selecting a database in the review article [28].

\section{STUDY SELECTION}

The initial database search results in 1288 published English-language articles. After removing the duplicate and irrelevant articles, we have shortlisted 220 articles related to the mental wellbeing of students. In these studies, only 21 articles were located through hand-searching the papers that discuss the critical challenges of the mental wellbeing of students. In the study, the six most critical barriers were concluded through comprehensive research literature considered to satisfy inclusion criteria.

\begin{tabular}{|l|l|l|l|l|l|l|}
\hline S. No. & Notation & Barriers & Description & References & \\
\hline 1. & BR1 & Academic & Academic-related stress, anxiety, and & (Subramani \& Kadhiravan \\
\hline
\end{tabular}




\begin{tabular}{|c|c|c|c|c|}
\hline & & $\begin{array}{l}\text { anxiety, } \\
\text { depression, } \\
\text { stress }\end{array}$ & $\begin{array}{l}\text { depression are linked with various factors } \\
\text { that are interpersonal relations with family } \\
\text { and friends. The high expectation from } \\
\text { parents to score good academic marks } \\
\text { pressurizes students' performance in higher } \\
\text { education and thus poses a negative impact } \\
\text { on adolescents' psychological well-being. } \\
\text { The competition from fellow members and } \\
\text { friends, poor relations, and low social } \\
\text { support are also responsible. }\end{array}$ & $\begin{array}{l}\text { Professor, n.d.)(Wahyuni et } \\
\text { al., n.d.) }\end{array}$ \\
\hline 2. & BR2 & $\begin{array}{l}\text { Socio- } \\
\text { Economic } \\
\text { Hardship } \\
\text { and Status }\end{array}$ & $\begin{array}{l}\text { The dissatisfaction arises from the living } \\
\text { standard and position in society. Students } \\
\text { with low socio-economic backgrounds } \\
\text { cannot reveal their problems in front of } \\
\text { their families, including the unequal } \\
\text { distribution of resources in society. }\end{array}$ & $\begin{array}{l}\text { (Lynch, 2016)(Thornicroft } \\
\text { \& Patel, 2014) }\end{array}$ \\
\hline 3. & BR3 & $\begin{array}{l}\text { Personal } \\
\text { factors }\end{array}$ & $\begin{array}{l}\text { It can be caused due to poor health, low } \\
\text { self-esteem, low self-confidence, low } \\
\text { intelligence, less focus on studies, } \\
\text { addiction to social media, lack of physical } \\
\text { exercise, less engagement in co-curricular } \\
\text { activities in college, Feeling of being } \\
\text { judged by classmates, students in higher } \\
\text { education do not feel to express their } \\
\text { feelings and emotions with others easily. It } \\
\text { has been seen as an addiction to the } \\
\text { consumption of alcohol, drugs, smoke, and } \\
\text { various harmful products that worsens } \\
\text { their mental and physical well-being. }\end{array}$ & $\begin{array}{l}\text { (Agrawal et } \\
2020)(\text { Vidourek al., } \\
2014 a)\end{array}$ \\
\hline 4. & BR4 & $\begin{array}{l}\text { Familial } \\
\text { factors }\end{array}$ & $\begin{array}{l}\text { The factors include the poor socio- } \\
\text { economic status, upbringing of adolescents } \\
\text { by divorced parents, concept of nuclear } \\
\text { families also plays a significant role in } \\
\text { students' behavior and decision-making } \\
\text { skill. The poor environment is indulged } \\
\text { more into domestic violence, negativity, } \\
\text { and disharmony between family members. } \\
\text { The authoritarian nature of parents with } \\
\text { the adolescent is a constraint for them. }\end{array}$ & $\begin{array}{l}\text { (Gulliver et } \\
\text { 2010)(Vidourek } \\
\text { 2014b) }\end{array}$ \\
\hline 5. & BR5 & $\begin{array}{l}\text { Technologi } \\
\text { cal factors }\end{array}$ & $\begin{array}{l}\text { There is a lack of access to gadgets, poor } \\
\text { internet connection, lack of technical } \\
\text { knowledge, lack of physical space. }\end{array}$ & $\begin{array}{l}\text { (Baticulon et } \\
\text { 2021)(Lister et al., 2021) }\end{array}$ \\
\hline 6. & BR6 & $\begin{array}{l}\text { Political } \\
\text { factors }\end{array}$ & $\begin{array}{l}\text { It plays a significant role in law and order } \\
\text { situations in a particular region, } \\
\text { infiltration, and fear of terrorism. The shift } \\
\text { from poor socio-economic area to urban } \\
\text { areas are at greater risk of maladjustment } \\
\text { because of the new environment. }\end{array}$ & $\begin{array}{l}\text { (Vidourek et al., 2014b) } \\
\text { (Glozah, F, 2013) }\end{array}$ \\
\hline
\end{tabular}




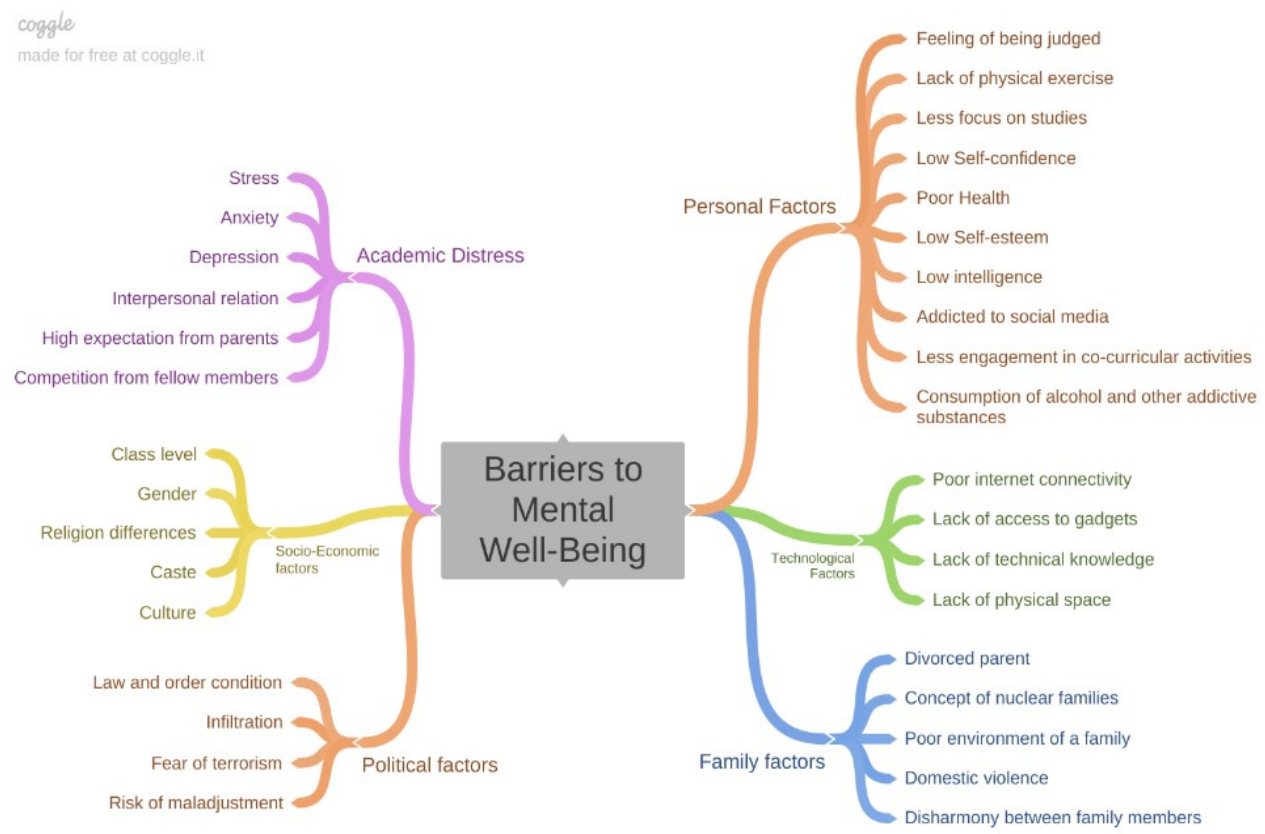

Figure 3: Virtual presentation of Barriers

\section{WELL-BEING AND SUSTAINABILITY IN HIGHER EDUCATION}

Education for sustainable development (ESD) encourages people to think differently from traditional thinking and contributes to a sustainable future. According to UNESCO, access to the quality of education at each level to transform the social circumstances by reorienting the education pattern and assist people in developing their skills, knowledge, values, and behavior is required for sustainable development. The Quality of education at this moment focuses on the social, emotional, mental, physical, and cognitive development of the students irrespective of their gender, caste, religion, ethnicity, and geographic location (Education for Sustainable Happiness and Well-Being - Catherine O'Brien - Google Books, n.d.). In the context of sustainable education, it implies four indicators: educational policies and practices that are sustaining, tenable, healthy, and durable. As per the sustainable development goals (SDG), one of the component measurement indicators is ESD [28].

\subsection{The Role of Sustainable Education in Promoting the Well-Being of the Students:}

Sustainability starts when the students are prepared to take charge of their prosperous future and welfare in professional life. Sustainable education can provide a medium to educate students about ways of focusing on their well-being (Education for Sustainable Happiness and WellBeing - Catherine O'Brien - Google Books, n.d.).

Enhancing Productivity: When individuals will become able to improve their productivity in every aspect, the community's well-being will proportionally be enriched. To achieve sustained living conditions, it is required to implement the necessary education that makes them aware of modern and innovative methods and techniques $[15,17]$.

Promotes Social Integration: Individuals in the educational sector come across various backgrounds. It includes race, caste, gender, educational qualification, and socio-economics background. ESD makes individuals aware of their equal rights and opportunity without discrimination $[13,26]$. The importance of sustainable education in the current era makes it a challenge for the people of a low level of education to maintain their social identity hence it can harm their self-esteem and well-being.

Sustainable education and modernization: In the era of advancement and modernization, sustainable education plays a positive role in accumulating a sustainable lifestyle [25]. Awareness among individuals makes the proper and efficient utilization of every resource at the utmost level. The next aspect of modernization is linked with attitude and perceptions [23] 
Inclination towards social, spiritual, and moral values: A study conducted shows empirical evidence that presents spirituality as a mediator between predictor variables and the mental health of students, among others $[4,14,18]$. Sustainable education focuses on values and morals; thus, it leads to a positive aspect of student's mental well-being and will help make correct decisions based on wisdom.

Sustainable education and human capital formation: According to a various economist like Mincer and Gary Backer has promoted the theory of human capital formation. Investing in human knowledge, education, skills, training, vocational skills will contribute towards a healthy life.

Sustainable Economy and Well-being in higher education: There is a positive correlation between economic growth, the well-being of students, and the achievement of the future with sustainability. The current generation must utilize the resources so that the future generation shall not get deprived of what they owe equal [10]. The role of educators in promoting sustainable education is somehow essential to incorporate equity, diversity, and inclusivity among students [28]. Education that is not just based on a traditional teaching and learning method but also includes vocational training, updating skills and practices, invention, and innovation according to society's need.

Social Sustainability and Well-being in higher education: Social sustainability can be seen in a broader sense to accomplish sustainability as a whole. They provide equal opportunity to all, access to all levels of education, and the inclusion of students of exceptional ability $[12,16]$. It can also be summarized as respect for the teachers, fellow members, and staff. To promote good relationships between learner and teacher, enhance the wellness of students [20,23, 29]. The inclusion of democracy, justice, equality, cultural diversity, human rights, anti-racism, and community. Valuing the principles, ethics, and values leads to gain in the required wisdom in students and hence can improve their mental well-being.

Environmental Sustainability and Well-being: Environment education started in 1970, focusing on creating awareness of the natural ecosystem and preventing its degradation. Environmental sustainability includes biodiversity, the environment, biospheres, wildlife, energy, and other resources. The inclusion of social sustainability in higher education also includes cultural sustainability and corporate sustainability $[19,21]$. Production and consumption of eco-friendly products, reusable products, or maximum utilization of such resources can be promoted via various projects and themes, which leads to the achievement of SDG [27].

\section{LIMITATION AND FUTURE SCOPE OF THE STUDY}

The present study reveals that the higher education sector in the Indian economy is still facing mental well-being problems. In the present study, only six critical barriers were found that can be implemented to enhance the mental well-being of adolescents of higher education in India with the adoption of Sustainable Development Goals, which could be helpful to achieve the SDG 2030. There are several limitations in the current study that need to be addressed. Firstly, the search approach may not have included all the relevant articles. The selection of a database directly influences the coverage of potential themes and journal papers. This review paper employed only three databases that convey that some of the related journals may not have been indexed by the selected database. Further, the coming literature can acknowledge the other related barriers by doing systematic or exploratory research. Additionally, in future it would be more interesting to address more related challenges and enablers related to mental well-being. Survey analysis can be done to investigate the effect on mental well-being on student life in which statistical analysis approaches or decision-making approaches can be applied.

\section{CONCLUSION}

To achieve SDG 3(Health and Well-being), education plays a significant role in achieving this objective by providing the required knowledge and information about the correct decisions in life in every aspect. Promoting the well-being of students is an important objective in the current era. Since, the education sector plays a significant role in designing humankind's future, it is required to promote many educational programs, strands, some holistic approaches, and the integration of theoretical and practical aspects to advance the mental well-being of students. The role of sustainability in building the paradigm of student development in coordination with global environmental change. In the $21 \mathrm{st}$ century, critical thinking and doing, communication skills, creative problem solving, student-centric, and sustainable living are considered important for society as a whole. At the national and international levels encompassing the student's well-being by providing access to nature in their respective 
campus. Activities like writing gratitude journals, positive affirmations, practices of meditation, breathing exercise and regular yoga should be kept mandatory by the universities. It is required to focus on the barriers parameters and seek the required solution; workshops and talk shows, are various ways to reduce such barriers. This paper has given insight into the importance of students' well-being in higher education and promotes sustainability and understanding the concept of well-being is not an incidental by-product but lifelong learning.

\section{AUTHORS' CONTRIBUTIONS}

All authors have contributed equally in the development of manuscript.

\section{ACKNOWLEDGMENTS}

The authors are thankful to reviewers for their comments and suggestions.

\section{REFERENCES}

[1] Agrawal, S., Sharma, N., \& Singh, M. (2020). Employing CBPR to Understand the WellBeing of Higher Education Students During Covid-19 Lockdown in India. SSRN Electronic Journal. https://doi.org/10.2139/ssrn.3628458

[2] Arunachalam, P. (2010). Higher Education Sector in India: Issues and Imperatives. In Journal of Global Economy (Vol. 6). http://dyuthi.cusat.ac.in/xmlui/handle/purl/4299

[3] Baticulon, R. E., Sy, J. J., Alberto, N. R. I., Baron, M. B. C., Mabulay, R. E. C., Rizada, L. G. T., Tiu, C. J. S., Clarion, C. A., \& Reyes, J. C. B. (2021). Barriers to Online Learning in the Time of COVID-19: A National Survey of Medical Students in the Philippines. Medical Science Educator, $1, \quad 3$. https://doi.org/10.1007/s40670-021-01231-z

[4] Boeren, E. (2019). Understanding Sustainable Development Goal (SDG) 4 on "quality education" from micro, meso and macro perspectives. International Review of Education, 65(2), 277-294. https://doi.org/10.1007/s11159-019-09772-7

[5] Cage, E., Stock, M., Sharpington, A., Pitman, E., \& Batchelor, R. (2020). Barriers to accessing support for mental health issues at university. Studies in Higher Education, 45(8), 1637-1649. https://doi.org/10.1080/03075079.2018.154423

7

[6] Chi-Kin Lee, J. (2020). Children's spirituality, life and values education: cultural, spiritual and educational perspectives. In International Journal of Children's Spirituality (Vol. 25, Issue 1, pp. 1-8). Routledge. https://doi.org/10.1080/1364436X.2020.179077 4

[7] Gloria, A. M., \& Ho, T. A. (2003). Environmental, Social, and Psychological Experiences of Asian American Undergraduates: Examining Issues of Academic Persistence. Journal of Counseling \& Development, $\quad$ 81(1), 93-105. https://doi.org/10.1002/j.15566678.2003.tb00230.x

[8] G. R. Meredith, D. A. Rakow, E. R. B. Eldermire, C. G. Madsen, S. P. Shelley, and N. A. Sachs, "Minimum Time Dose in Nature to Positively Impact the Mental Health of CollegeAged Students, and How to Measure It: A Scoping Review," Front. Psychol., vol. 10, p. 2942, Jan. 2020, doi: 10.3389/fpsyg.2019.02942

[9] Gulliver, A., Griffiths, K. M., \& Christensen, H. (2010). Perceived barriers and facilitators to mental health help-seeking in young people: A systematic review. BMC Psychiatry, 10(1), 113. https://doi.org/10.1186/1471-244X-10-113

[10] Izutsu, T., Tsutsumi, A., Minas, H., Thornicroft, G., Patel, V., \& Ito, A. (2015). Mental health and wellbeing in the Sustainable Development Goals. In The Lancet Psychiatry (Vol. 2, Issue 12, pp. 1052-1054). Elsevier Ltd. https://doi.org/10.1016/S2215-0366(15)00457-5

[11] Kioupi, V., \& Voulvoulis, N. (2020). Sustainable Development Goals (SDGs): Assessing the Contribution of Higher Education Programmes. Sustainability, 12(17), 6701. https://doi.org/10.3390/su12176701

[12] Kapur, R. (n.d.). International Journal of Development in Social Sciences and Humanities HISTORICAL DEVELOPMENT OF SECONDARY EDUCATION. JOURNAL OF DEVELOPMENT IN SOCIAL SCIENCES AND HUMANITIES, 7, 2019. Retrieved April 19, 2021, from http://www.ijdssh.com

[13] Lister, K., Seale, J., \& Douce, C. (2021). Mental health in distance learning: a taxonomy of 
barriers and enablers to student mental wellbeing. Open Learning. https://doi.org/10.1080/02680513.2021.189990 7

[14] Lynch, T. (2016). United Nations Sustainable Development Goals: Promoting health and wellbeing through physical education partnerships. Cogent Education, 3(1), 1188469. https://doi.org/10.1080/2331186X.2016.118846 9

[15] Michalos, A. C. (n.d.). Education, Happiness and Wellbeing. https://doi.org/10.1007/s11205007-9144-0

[16] O’Brien, C. (2012). Sustainable Happiness and Well-Being: Future Directions for Positive Psychology. Psychology, 03(12), 1196-1201. https://doi.org/10.4236/psych.2012.312A17

[17] Pauw, J., Gericke, N., Olsson, D., \& Berglund, T. (2015). The Effectiveness of Education for Sustainable Development. Sustainability, 7(11), 15693-15717.

https://doi.org/10.3390/su71115693

[18] S. Agrawal, A. Jamwal, and S. Gupta, "Effect of COVID-19 on the Indian Economy and Supply Chain," May 2020, doi: 10.20944/preprints202005.0148.v1.

[19] S. Bhatnagar, S. Agrawal, D. Sharma, and M. Singh, "Perception on the Community Engagement of Students of Higher Education Institutions," SSRN Electron. J., Aug. 2020, doi: 10.2139/ssrn.3664052.

[20] Subramani, C., \& Kadhiravan Professor, S. (n.d.). ACADEMIC STRESS AND MENTAL HEALTH AMONG HIGH SCHOOL STUDENTS.

[21] Sweileh, W. M. (2020). Bibliometric analysis of scientific publications on "sustainable development goals" with emphasis on "good health and well-being" goal (2015-2019). In Globalization and Health (Vol. 16, Issue 1, pp. 1-13). BioMed Central. https://doi.org/10.1186/s12992-020-00602-2

[22] Thornicroft, G., \& Patel, V. (2014). Including mentalhealth among the new sustainable development goals. In BMJ (Online) (Vol. 349). BMJ Publishing Group. https://doi.org/10.1136/bmj.g5189
[23] Teixeira, R. J., Brandão, T., \& Dores, A. R. (2021). Academic stress, coping, emotion regulation, affect and psychosomatic symptoms in higher education. Current Psychology, 1-10. https://doi.org/10.1007/s12144-020-01304-Z

[24] Venkataraman, B. (2009). Education for sustainable development. Environment, 51(2), 8-10. https://doi.org/10.3200/ENVT.51.2.08-10

[25] Vidourek, R. A., King, K. A., Nabors, L. A., \& Merianos, A. L. (2014). Students' benefits and barriers to mental health help-seeking. Health Psychology and Behavioral Medicine, 2(1), 1009-1022.

https://doi.org/10.1080/21642850.2014.963586

[26] Wahyuni, E. N., Aziz, R., \& Mangestuti, R. (n.d.). Family, Spirituality, and Mental Health in Higher Education Why do private Madrasah Ibtidaiyah teachers have teaching resilience? View project sunita View project Family, Spirituality, and Mental Health in Higher Education. https://doi.org/10.5220/0008589703760385

[27] Wilhelm, K., Wedgwood, L., Parker, G., Geerligs, L., \& Hadzi-Pavlovic, D. (2010). Predicting Mental Health and Well-Being in Adulthood. Journal of Nervous \& Mental Disease, 198(2), 85-90. https://doi.org/10.1097/NMD.0b013e3181cc41d d

[28] Y. Wang, "College students' trait gratitude and subjective well-being mediated by basic psychological needs," Soc. Behav. Pers., vol. 48, no. 4, 2020, doi: 10.2224/sbp.8904.

[29] TK Satpathy, S Samanta, Influence of Spiritual Intelligence on human psychology- a review, Wutan Huatan Jisuan Jishu 16 (X) (2020) 